Race and Racism in Britain 
Also by John Solomos

Racism and Equal Opportunity Policies in the 1980s (editor, with Richard Jenkins)

The Roots of Urban Unrest (editor, with John Benyon)

Black Youth, Racism and the State

Race and Local Politics (editor, with Wendy Ball)

Racism and Migration in Western Europe (editor, with John Wrench) 


\title{
Race and Racism in Britain
}

Second Edition

\author{
John Solomos
}

Reader in Public Policy

Birkbeck College

University of London

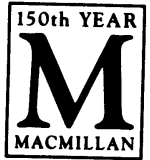


All rights reserved. No reproduction, copy or transmission of this publication may be made without written permission.

No paragraph of this publication may be reproduced, copied or transmitted save with written permission or in accordance with the provisions of the Copyright, Designs and Patents Act 1988, or under the terms of any licence permitting limited copying issued by the Copyright Licensing Agency, 90 Tottenham Court Road, London W1P 9HE.

Any person who does any unauthorised act in relation to this publication may be liable to criminal prosecution and civil claims for damages.

First published as Race and Racism in Contemporary Britain in 1989 Reprinted 1990, 1991, 1992

Second edition 1993

Published by THE MACMILLAN PRESS LTD

Houndmills, Basingstoke, Hampshire RG21 2XS

and London

Companies and representatives throughout the world

ISBN 978-0-333-59329-5 ISBN 978-1-349-22911-6 (eBook)

DOI 10.1007/978-1-349-22911-6

A catalogue record for this book is available from the British Library.

Copy-edited and typeset by

Povey-Edmondson

Okehampton and Rochdale, England 
To the memory of Cleopatra, Solomos, Styliani and Yiannis, who missed out on the opportunities I have enjoyed, but whose experiences remain with me 


\section{Contents}

Preface to the First Edition xi

Preface to the Second Edition xiii

Introduction 1

Recent trends and developments 2

Key questions 3

Racism in contemporary Europe $\quad 5$

Focus of study $\quad 6$

Plan of the book 9

1 Theories of Race and Racism 13

$\begin{array}{ll}\text { Introduction } & 13\end{array}$

Approaches to the study of race relations $\quad 14$

$\begin{array}{ll}\text { The sociology of race in Britain } & 17\end{array}$

Politics, power and racism 21

Critiques of the race relations problematic 25

Culture, community and identity 31

What kind of alternative? 33

Summary and conclusion $\quad 35$

2 Historical Background and Context 38

Introduction $\quad 38$

The historical context of racism in Britain 39

Anglo-Saxons and Celts $\quad 40$

Political and ideological responses to Jewish immigration 43

Race and labour in the early twentieth century 47

Summary and conclusion $\quad 51$

3 The Politics of Race and Immigration since 1945

Introduction 52

The post-1945 conjuncture and European migration 53

Migration, colonial labour and the state: 1945-62 56

Immigration and racialised politics $\quad 59$

Immigration controls and state racism 61 
The 1962 Commonwealth Immigrants Act 63

The changing terms of political debate 64

Institutionalising immigration controls 68

Immigration and race since $1979 \quad 70$

Prospects for reform $\quad 74$

$\begin{array}{ll}\text { Summary and conclusion } & 77\end{array}$

4 Race Relations Policies and the Political Process 78

$\begin{array}{ll}\text { Introduction } & 78\end{array}$

Racism and racial discrimination $\quad 79$

Race relations legislation in context $\quad 80$

The origins of anti-discrimination legislation $\quad 82$

The genesis of race relations policies $\quad 83$

The 1976 Race Relations Act $\quad 85$

From policy to practice $\quad 89$

Proposals for reform $\quad 91$

Summary and conclusion $\quad 93$

5 Urban Politics and Racial Inequality 95

Introduction $\quad 95$

Concepts and models of local politics 95

Race and local politics in historical perspective 96

Processes of racialisation $\quad 98$

Models of policy change $\quad 101$

$\begin{array}{ll}\text { Policy change and conflict } & 102\end{array}$

Pressures for change and their impact 105

Resistance to change 106

Positive action and new initiatives 108

Training and racial equality 113

Changing forms of local governance $\quad 116$

Summary and conclusion 118

6 Race, Policing and Disorder 120

$\begin{array}{ll}\text { Introduction } & 120\end{array}$

Race, crime and disorder 120

Alienated youth and ghetto life $\quad 124$

Poíicing minority communities 127

Mugging and street violence $\quad 130$

Racialisation and popular images 136

Policing and violent disorder 139 
Race, crime and statistics

7 Protest, Racism and Urban Unrest in the 1980s

Disorder and urban unrest

Explanations of urban unrest

Law and disorder

Racial disadvantage and urban unrest $\quad 156$

Alienation and powerlessness 158

Power, legitimacy and political disorder $\quad 160$

Policing after the riots $\quad 165$

Scarman and beyond 169

$\begin{array}{ll}\text { The changing politics of policing } & 174\end{array}$

$\begin{array}{ll}\text { Summary and conclusion } & 178\end{array}$

8 Racism, Nationalism and Political Action 180

$\begin{array}{lr}\text { Introduction } & 180\end{array}$

Changing forms of racial ideology $\quad 181$

$\begin{array}{ll}\text { Conceptions of race and nation } & 184\end{array}$

New-right ideologies and national identity 186

$\begin{array}{ll}\text { Neo-fascist politics } & 188\end{array}$

The politics of racial attacks 191

Racialised politics and the enemy within 192

$\begin{array}{ll}\text { Naturalisation of racism } & 193\end{array}$

Anti anti-racism 194

Nationalism and the interests of the majority 196

$\begin{array}{ll}\text { Summary and conclusion } & 197\end{array}$

9 Race, Politics and Mobilisation 198

Introduction 198

Political participation and exclusion 199

The context of black political participation 200

Origins of black political mobilisation $\quad 202$

Forms of black political organisation 203

Anti-racist politics and political alliances 211

The politics of race and class $\quad 212$

Politics, social movements and reform $\quad 214$

Summary and conclusion $\quad 216$ 
10 Race, Culture and Social Change 218 Introduction $\quad 218$

Imagined communities $\quad 219$

Multiculturalism, identity and the nation 221

Rushdie and Islam 222

Nationality and immigration $\quad 227$

Social and economic change $\quad 229$

Summary and conclusion 231

11 Changing Dynamics of Race and Racism 233

Introduction 233

Racism, politics and ideology 234

Equality or symbolic reforms?

Protest and social change $\quad 239$

Rethinking the politics of racism 241

Racism and nationalism in Europe $\quad 244$

What kind of future? 246

Guide to Further Reading 249

$\begin{array}{ll}\text { Bibliography } & 252\end{array}$

Index 273 


\section{Preface to the First Edition}

I would like to thank all the colleagues, students and friends who have helped me to articulate the arguments which are developed in this book. Since 1982 I have taught a number of courses on the politics of racism and related issues, and this has allowed me to test out some of the early versions of chapters included in this volume. I also owe a special debt to my former colleagues at the Centre for Research in Ethnic Relations, University of Warwick, who provided support and a challenging intellectual environment in the initial stages of writing. My present colleagues in the Department of Politics and Sociology at Birkbeck College have given me the space and encouragement to complete this study, and without their support it would have been much delayed. A number of other academic colleagues have given me help and support, in particular Bob Benewick, John Benyon, Mike Cowen, Andrew Gamble, Clive Harris, Bob Jessop, Michael Keith, Bob Miles and Solomos Solomou. Equally I have benefited from the superb collection of materials on race relations brought together by Heather Lynn at Warwick, which has no doubt saved me many hours of searching. At Warwick I received valuable administrative and secretarial support from Rose Goodwin, Gurbakhsh Hundal and Charlotte Wellington. At Birkbeck I have benefited from the invaluable secretarial support of Audrey Coppard and Harriet Lodge. My students at Birkbeck during 1987-88 were the unknowing recipients of some parts of this book in the form of lectures, and their comments helped me to sharpen my ideas and to organise this volume somewhat differently.

I owe a deep debt to my publisher, Steven Kennedy, for his support of the project despite unforeseen delays. At a personal level my family has provided me with necessary emotional support. Friends in Birmingham and London have seen the project develop and helped me to relax when I needed to. George and Ian were good company on our various trips to watch West Bromwich Albion, and they and the 'Baggies' deserve a special thanks. Christine Dunn helped to keep me going even when the labour got too much. This book is dedicated with much love to my grandparents.

Birkbeck College, London

JOHN SOLOMOS 


\section{Preface to the Second Edition}

For the second edition of this book I have chosen to rewrite all the chapters and to add additional material. This is partly the result of the pace of change even in the relatively short period since the first book was produced. Already in the past few years political debates about racial and ethnic issues have taken on new forms in both Britain and other European societies. Racist and nationalist movements have helped to further politicise debates about the role of immigration and the position of ethnic minorities. We have also seen the emergence of new forms of political and social mobilisation by minorities themselves. The changes I have introduced also reflect my own continuing attempts to come to terms with some of the key issues which this book covers. This can be seen in the new material included in Chapters 1, 5, 6 and 10, as well as in the changes I have introduced in other chapters. In including this material I have listened to the suggestions both of my students and my colleagues, and I hope this makes this edition more useful to both the specialist and the general reader.

In producing the second edition of this book I am grateful for the help and advice I have received from a number of colleagues and friends, who have helped me to revise and elaborate my argument. My greatest debt is to Les Back with whom I have worked closely over the past three years and who has influenced the content of a number of chapters in ways too numerable to mention. My students at Birkbeck College have proved a critical and supportive audience and they have helped me to clarify my ideas. The participants in the Workshop on the Politics of Racism, which has met at Birkbeck since 1988 , have helped me to develop my ideas in a number of productive directions. In particular I am grateful to Clive Harris, Michael Keith and Syd Jeffers who have all helped to keep the Workshop a friendly place to try out tentative ideas. Terry Mayer and Joanne Winning have provided a supportive environment at Birkbeck while I was producing this second edition and made sure I was not overwhelmed by administration and that I kept to my deadline. Steven Kennedy once again encouraged and supported the production of this edition. Since the production of the first edition the 'Baggies' have introduced me to the delights of third division football, an experience that has 
proved too much at times but which has at least allowed me to visit many new grounds and produced many enjoyable Saturday afternoons looking on the bright side of life.

Birkbeck College, London

JOHN SOLOMOS 